The Labor Market Structure of Transportation Sector in Indonesia: Digital Economy, Investment, Pandemic COVID-19, Job Creation Law
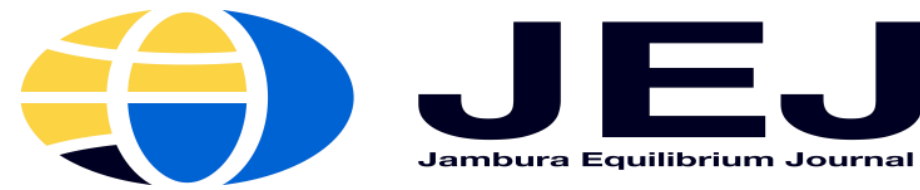

Volume 3. Issue 2. 2021

P-ISSN 2655-9110

E-ISSN 2656-0445

http://ejurnal.ung.ac.id/index.php/equij

\title{
The Labor Market Structure of Transportation Sector in Indonesia: Digital Economy, Investment, Pandemic COVID-19, Job Creation Law
}

\author{
Suparna Wijaya \\ Politeknik Keuangan Negara, Banten, Indonesia
}

\begin{abstract}
The development of the digital economy leads to the loss of several jobs and the emergence of new jobs. It also allows labor shifting between the new jobs and the old jobs. This phenomenon could raise the potential for unabsorbed labor which will cause unemployment problems. The COVID-19 pandemic, which requires large-scale social restrictions (PSBB), has certainly affected the transportation sector. This study aims to examine the influence of the digital economy, investment, the COVID-19 pandemic, and the Job Creation Law on the labor market structure of the transportation sector in Indonesia. The research method used is quantitative. The data used are the time series from January 2018 to November 2020. The results of this study indicate that the digital economy has no effect on the structure of the labor market in the transportation sector in Indonesia. Meanwhile, investment, the COVID-19 pandemic, and the Job Creation Law, respectively, have a significant effect on the structure of the labor market in the transportation sector in Indonesia. The impact of investment and the COVID-19 pandemic on the labor market structure of the transportation sector in Indonesia is negative. Meanwhile, the effect of the Job Creation Law on the labor market structure of the transportation sector in Indonesia is positive. Simultaneously, the digital economy, investment, the COVID-19 pandemic, and the Job Creation Law affect the labor market structure of the transportation sector in Indonesia.
\end{abstract}

Keywords: Labor Market; Labor Shifting; Omnibus Law; Economic Crisis

\section{INTRODUCTION}

The development of information and communication technology changes economic activity. Australia's Digital Economy in Wijaya and Utamawati (2019) defined the digital economy as a social and economic activity in a global network with the support of the internet or information and communication technology. The OECD in 2015 argued that the digital economy grew broadly including trade (ecommerce), education (e-learning), social media, transportation, and even health (digital medical records). In 2015 or 24 years after www was introduced, the internet even has bridged the interactions of more than $50 \%$ of the world's population. Based on data from the Indonesian Internet Service Providers Association (APJII) in 2020, 196.71 million active internet users or $73.7 \%$ of Indonesia's population in 2019 use the internet for more than four hours a day. 
Labor shifting is a phenomenon in which labor shifts from one sector to another. During the economic crisis in 1998, labor shifting occurred from high productivity sectors to low productivity sectors to avoid unemployment (Permata et al., 2010). Labor shifting also occurs from routine jobs and low education to jobs that require creativity and social intelligence with low automation (Frey \& Osborne, 2013). This labor shifting causes the possibility of unabsorbed labor. Furthermore, the existence of unabsorbed workforce will cause unemployment. Unemployment itself is a problem for a country. In Indonesia, the unemployment rate according to World Bank data in 2020 is $4.84 \%$ of the total workforce. This number is higher than the average number of countries in East Asia and the Pacific which is only $3.89 \%$. However, the unemployment rate in Indonesia is still better than Upper Middle Income countries in general, which have an unemployment rate of $5.99 \%$.

The development of the digital economy, which can have a positive or negative effect on the labor market, has attracted the attention of researchers to conduct research. This research will be carried out using variables such as the digital economy, investment, the COVID19 pandemic, and the Job Creation Act. Researchs related to the influence of the digital economy on the structure of the labor market has been carried out several times in Indonesia. Wisana et al. (2017) found that Go-Jek reduce unemployment and create jobs. However, the research conducted is only based on a survey. Paundralingga's research (2018) has found that Go-Jek can also absorb labor. The research on the effect of the digital economy that will be carried out is different from previous research. In this research, the proxies of electronic money that are widely used in the digital economy are used.

Researchs related to the effect of investment on the labor market is also interesting because previous studies have not obtained the same results. Dimas \& Woyanti (2009) explain that investment has a negative effect on labor absorption. However, Sulistiawati (2012) succeeds in explaining that investment will absorb labor or have a positive effect. Meanwhile, Wasilaputri (2016) found the different result, namely investment has no effect on labor absorption.

The research also uses the influence of the COVID-19 pandemic on the labor market. This is interesting because in early 2020, the COVID-19 pandemic began to enter Indonesia. Cakranegara (2020) found that the COVID-19 pandemic reduced labor absorption. However, the study only used descriptive analysis.

The research also uses the effect of the Job Creation Act on the labor market. The existence of this law is expected to create an ease of doing business. Furthermore, the ease of doing business can create jobs including jobs for foreign workers (Jumanah, 2020; Hanifah, 2021). Both studies are law studies that analyze the potential entry of foreign workers to Indonesia after the Job Creation Law began to take effect.

\section{Labor Market}

Demand, according to Sudarsono, is the maximum amount of goods or services needed by buyers at a certain price and time (Sholeh, 2007). Furthermore, as explained by Miller \& Meiners (1997), the marginal value of product has an effect on labor demand. The marginal value of product is the marginal physical product times the price of a product. The marginal physical product itself is the change in the level of 
The Labor Market Structure of Transportation Sector in Indonesia: Digital Economy, Investment, Pandemic COVID-19, Job Creation Law

Email: sprnwijaya@pknstan.ac.id

product that comes from an increase or decrease in one unit of its variable input which is labor. Meanwhile, the labor supply in Sholeh (2007) is the amount of labor that can be provided by users of labor for a certain wage and time. GS Becker in Sholeh (2007) explains that individuals can get satisfaction by consuming or enjoying time, which is constrained by the level of income and time. Layard and Walters in Sholeh (2007) explain that the level of wages and non-work income affects individual decisions regarding leisure time. Government policies to increase minimum wages also need to be considered because high minimum wages will increase the use of digital technology (Packard \& Montenegro, 2017).

\section{The Influence of The Digital Economy on The Structure of Labor Market}

The digital economy is "the virtual arena in which business is conducted, value is created and exchanged, transactions occur, and one-to-one relationship is mature by using any internet initiative as medium of exchange (Hartman et al., 2001). Its existence can be seen from the growing development of business or trade transactions with the use of the internet as a medium for communication, collaboration and cooperation between companies or between individuals. The digital economy is an economic activity based on the internet digital technology. The digital economy is also called the internet economy, digital-based economy, new economy knowledge, or new economy (Tapscott, 1996). Acemoglu (1999) explained that theoretically information technology changed the job creation process for companies. Meanwhile, Jaimovich and Siu (2012), in sectoral data, found that a long process of technical change led to the loss of intermediate skill jobs during a recession. Autor, Levy and Murnane (2003) found that computerization replaced workers who performed routine, cognitive tasks and complemented workers who performed non-agile tasks. Gray (2013) studied employment-level evidence from the first half of the 20th century and found that electrification correlates with a shift from work-intensive agility skills, similar to the findings of Autor, Levy and Murnane (2003) for computerization in the late 20th century. Woolf (1984) found that firms seeked labor-saving techniques and use of capital in response to cheaper energy and a reduction of the share of labor income. Morin (2016) found that electricity causes capital intensity to increase, decreases labor demand, and has no effect on output. The effect was stronger in countries in which depression was more severe. Swiecki (2017) found that technological change is the main driving factor for changes in the structure of the labor market. Frey and Osborne (2013) found that computerization risks job loss. A research conducted by Woetzel et al. (2014) in China also found that the internet had a positive impact on the labor market despite some disruptions as a number of jobs disappeared.

\section{The Effect of Investment on the Labor Market}

Investment is purchasing one or more assets owned and usually have a long term with the expectation of getting benefits in the future (Sunariyah, 2013). Jogiyanto (2014) defines investment as a postponement of current consumption to be allocated to productive assets for a certain period. Meanwhile, Gitman and Joehnk (2010) explain investment as a means of placing funds in the hope of earning income and maintaining or increasing their value. Investments will absorb labor (Sulistiawati, 
The Labor Market Structure of Transportation Sector in Indonesia: Digital Economy, Investment, Pandemic COVID-19, Job Creation Law

Email: sprnwijaya@pknstan.ac.id

2012). However, Dimas \& Woyanti (2009) found that investment has a negative effect labor absorption. Meanwhile, Wasilaputri (2016) found that investment has no effect on labor absorption.

\section{The Effect of COVID-19 Pandemic on the Labor Market}

COVID-19 pandemic has impacts not only on the level of public health, but also on the Indonesian economy. Many companies have had to stop their business activities in an effort to prevent this virus. In fact, many employees have contracted this virus. The COVID-19 pandemic has an impact on the economy which results in labor absorption (Cakranegara, 2020)

\section{The Job Creation Law on the Labor Market}

Job Creation Law is expected to make it easier for entrepreneurs to do business. Furthermore, the ease of doing business will create jobs including foreign workers (Jumanah, 2020; Hanifah, 2021).

\section{Research Hypotheses}

The formulation of hypothesis testing refers to the theory described and previous research, namely as follows:

H1: The digital economy affects the labor market structure of the transportation sector

H2: Investment affects the labor market structure of the transportation sector

H3: The COVID-19 pandemic affects market structure transportation sector workers

H4: The Job Creation Law affects the labor market structure of the transportation sector.

\section{METHODOLOGY}

This study uses quantitative data, namely data in the form of numbers or qualitative data converted into numbers. The data is processed and analyzed in order to obtain a conclusion. The conclusion that will be obtained in this research is a form of influence between independent variables and dependent variables. In analyzing data, this study uses descriptive statistics. Sugiyono (2016) defines descriptive statistics as statistics that aim to describe data without drawing conclusions. Furthermore, the variables are analyzed using regression analysis, which is a technique in statistics to assess the effect of several variables and predict other variables (Kutner et.al, 2004).

The type of data used in this study is secondary data. Sugiyono (2016) explains that secondary data is a collection of data indirectly sourced from other parties. The party indirectly provides data that has been processed so that it can be presented to other parties. This study uses time series data. Time series data is a collection of observations in a time span collected in continuous time intervals (Widarjono, 2007).

The research variable is something that the researcher determines to study so that the results of the information are used for making conclusions (Sugiyono, 2016). Sekaran (2016) explains that the dependent variable (dependent) is a variable that becomes the main goal to be achieved in research. Sugiyono (2016) defines the dependent variable as a variable that is influenced by the independent variable. The dependent variable in this study is the structure of the transportation sector labor market (TRANS). The proxy for the labor market structure of the transportation sector used by researchers is the number of 
The Labor Market Structure of Transportation Sector in Indonesia: Digital Economy, Investment, Pandemic COVID-19, Job Creation Law

Email: sprnwijaya@pknstan.ac.id

monthly airplane passengers based on data from the Central Statistics Agency and PT Angkasa Pura I and II.

The independent variable is a variable whose value is not influenced or determined by other variables in the model.
The independent variables of this research are the digital economy, investment, the COVID-19 pandemic, and the Job Creation Law. The operational definition of the independent variable is as follows:

\begin{tabular}{|l|l|l|}
\hline Variable & \multicolumn{1}{|c|}{ Operational Definition } & \multicolumn{1}{c|}{ Data Source } \\
\hline ED & The amount of electronic money & Bank Indonesia \\
\hline INV & Composite Stock Price Index & Bank Indonesia \\
\hline COV & Pandemic COVID dummy variable & $\begin{array}{l}\text { Ministry of Health, National Disaster } \\
\text { Relief Agency }\end{array}$ \\
\hline UUCK & Job Creation Law dummy variable & $\begin{array}{l}\text { Regional House of Representatives, } \\
\text { Ministry of Law and Human Rights }\end{array}$ \\
\hline
\end{tabular}

Based on the hypothesis built on the theoretical basis and the variables mentioned in the previous section, the author proposes a simultaneous research model as follows:

TRANSt $=\alpha 0+\beta 1 \mathrm{EDt}+\beta 2 \mathrm{INVt}+$ $\beta 3 \mathrm{COVt}+\beta 4 \mathrm{UUCKt}+\varepsilon \mathrm{t}$

Information:

TRANS $=$ Labor market structure in the transportation sector $\mathrm{t}=$ Month (January 2018 to November 2020)

$\begin{array}{lll}\text { ED } & = & \text { Digital economy } \\ \text { INV } & = & \text { Investment } \\ \text { COV } & = & \text { Covid pandemic19 } \\ \text { UUCK } & = & \text { Job Creation Law }\end{array}$

\section{RESULTS AND DISCUSSION}

\section{Descriptive Analysis}

Descriptive statistical analysis aims to provide an overview of the tendency and distribution of data. This analysis seeks to describe the data that has been collected as it is without intending to make generally accepted conclusions (Sugiyono, 2016). The analysis used is mean, median, and mode for some variables. The mean is the average value of each variable for the entire company over a period of four years, the median is the middle value of a group of observations after being sorted from the smallest value, while the mode is the value that appears most frequently in the data set. Apart from these three measures, there are data dispersion measures used in this study, namely the highest (maximum) and lowest (minimum) values and the standard deviation (std.dev) which describe how close the individual data points are to the mean. 
The Labor Market Structure of Transportation Sector in Indonesia: Digital Economy, Investment, Pandemic COVID-19, Job Creation Law

Table 1. Descriptive Analysis

\begin{tabular}{|l|c|c|c|c|c|}
\hline & TRANS & ED & INV & COV & UUCK \\
\hline Mean & 2678656. & $2.38 E+08$ & 5.868 .137 & 0.257143 & 0.057143 \\
\hline Median & 3188261. & $2.10 E+08$ & 6.011 .830 & 0.000000 & 0.000000 \\
\hline Maximum & 4327145. & $4.20 E+08$ & 6.605 .630 & 1.000 .000 & 1.000 .000 \\
\hline Minimum & 45576.00 & 97163539 & 4.538 .930 & 0.000000 & 0.000000 \\
\hline Std. Dev. & 1189178. & $1.04 E+08$ & 5.966 .493 & 0.443440 & 0.235504 \\
\hline
\end{tabular}

Source: Processed from the test results with EViews11

\section{Classical Assumption Test}

After the panel data regression model is selected, the next step is to perform the classical assumption test. The classical assumption test is done to ensure that the regression model meets the BLUE assumption (Best Linear Unbiased Estimate). The classical assumption test consisted of the non-heteroscedasticity test, the non-autocorrelation test, and the normality test. The stages and results of each classical assumption test are as follows.

1. Normality Test

The non-normality test is used to see whether the model in the regression has confounding or error variables that are normally distributed or not (Gujarati, 2009). This non-normality test is carried out using the Jarque Bera test and looking at the normality graph processed from the EViews11 application. The Jarque-Bera test results show the results of the non-normality test. The probability of Jarque Bera is worth 0.036695 which is significant at $\alpha=0.05$. This value causes acceptance of Ha, which means that the residuals are not normally distributed. Although the residuals are not normally distributed, based on the Central Limit Theorem (CLT), the sampling distribution curve with a sample of 30 or more will center on the population parameter values and will have all the characteristics of a normal distribution (Aistleitner \& Berkes, 2010; Bardet et al., 2008 ; Bellhouse, 2001; Colburn, 2009; Dassau \& Hasbun, 2004; Franke, 2005; Johansen \& Nielsen, 2012; Notohara, 2010; Park et al., 2009; Shashkin, 2006; Xia, 2009; Yu et al., 2012).

2. Non-heteroscedasticity Test

The non-heteroscedasticity test is a classical assumption test in regression which is useful for assessing whether there is an inequality of variance from the residuals for all observations in the linear regression model or not. The nonheteroscedasticity test aims to test whether in the regression model there is an inequality of residual variants from one observation to another (Ghozali, 2013). A good regression model should fulfill homoscedastic assumptions, that is, a model with a variant that has a fixed residual value from one observation to another. Ha is accepted if Breusch-Pagan LM is significant less than $\alpha=0.05$. In contrast, the value of Prob. more than 0.05 will reject $\mathrm{Ha}$ and accept H0, which means that the research model is free from heteroscedasticity problems. The $p$ 
The Labor Market Structure of Transportation Sector in Indonesia: Digital Economy, Investment, Pandemic COVID-19, Job Creation Law

value is indicated by the Prob value. chi square (6) on Obs * $\mathrm{R}$-Squared is 0.5483 . Because the $\mathrm{p}$ value is $0.5483>$ $0.05, \mathrm{H} 0$ is accepted which means that the regression model is homoscedastic. In other words, there is no problem with the assumption of nonheteroscedasticity.

3. Non-autocorrelation Test

Non-autocorrelation test aims to determine whether there is a correlation between residuals in one observation and other observations in the regression model. This test can indicates a correlation between the variables in the prediction model regarding changes in time. A good regression model is a regression model that is free from autocorrelation problems. In this study, autocorrelation was tested using the Breusch-Godfrey Serial Correlation LM Test with EViews11 application because no lag variable is used in the research model. Note the value of Prob Chi Square (2) which is the value $p$ value of the Breusch-Godfrey Serial Correlation LM test, which is equal to 0.4389 in which $>0.05$ so that $\mathrm{H} 0$ is accepted. It means that there is no serial autocorrelation problem.

4. Non-multicollinearity Test

Multicollinearity is a condition showing a correlation between two or more independent variables in a regression model. Multicollinearity does not reduce the power of predictions simultaneously, but affects the predicted value of the variables experiencing multicollinearity. Multicollinearity test is conducted to determine whether there is a correlation between independent variables or not. A good regression model should not have a strong relationship or correlation between the independent variables. Researchers tested Variance Inflation
Factors (VIF) using the VIF command in EViews11 application. If the VIF value of each variable and / or the average VIF value touches 10 , the data has a multicollinearity problem. The table shows that there are no variables that have a Centered VIF value of more than 10 , so it can be concluded that there are no symptoms of multicollinearity in the research data used.

5. Linearity Test

Linearity test is used to form new models and is BLUE (Best Linear Unbiased Estimation). Linearity test was performed using the Ramsey Reset Test. The $p$ value shown in the probability column of the F-statistics row is 0.4919 or $>0.05$, so it can be concluded that the independent variable is linear with the dependent variable.

\section{Regression Test}

1. Simultaneous Test (F-test)

Simultaneous significance test (F-test) is used to see the effect of all independent variables simultaneously on the dependent variable. In other words, the F-test of this study was conducted to test the influence of variables of the Digital Economy, Investment, the COVID-19 Pandemic, and the Job Creation Law on the variables of the Transportation Sector Labor Market Structure. After the F-test is carried out, the researcher looks at the probability of the F-statistic on the regression results that have been done. The independent variable is considered to be proven to affect simultaneously the dependent variable if the probability value of the F-statistic is smaller than the value of $\alpha=0.05$. The hypothesis that applies to the F-test is as follows. 
The Labor Market Structure of Transportation Sector in Indonesia: Digital Economy, Investment, Pandemic COVID-19, Job Creation Law

$\mathrm{HO}$ : the independent variables in the study simultaneously have no effect on the labor market structure of the transportation sector

$\mathrm{Ha}$ : the independent variables in the study simultaneously affect the labor market structure of the transportation sector.

Based on the regression conducted, the probability value of the F-statistic shows the number 0.000000 . This value is smaller than the value of $\alpha=0.05$ so that $\mathrm{HO}$ is rejected and $\mathrm{Ha}$ is accepted, which means that the independent variables in the study simultaneously affect the structure of the labor market in the transportation sector. The results of the F-test carried out can be seen in the table of F-test results.

Table 2. Regression Test Result

\begin{tabular}{|c|c|c|c|c|}
\hline \multicolumn{5}{|c|}{$\begin{array}{l}\text { Dependent Variable: TRANS } \\
\text { Method: Least Squares } \\
\text { Date: 01/22/21 Time: } 11: 30 \\
\text { Sample: } 135 \\
\text { Included observations: } 35\end{array}$} \\
\hline Variable & Coefficient & Std. Error & t-Statistic & Prob. \\
\hline C & 9110665. & 2223522. & 4.097402 & 0.0003 \\
\hline ED & -0.002666 & 0.001554 & -1.715325 & 0.0966 \\
\hline INV & -862.9158 & 351.2028 & -2.457030 & 0.0200 \\
\hline cov & -3089530 & 553037.1 & -5.586479 & 0.0000 \\
\hline UUCK & 1056495. & 474882.8 & 2.224748 & 0.0338 \\
\hline R-squared & 0.817973 & \multirow{7}{*}{\multicolumn{2}{|c|}{$\begin{array}{l}\text { Mean dependent var } \\
\text { S.D. dependent var } \\
\text { Akaike info criterion } \\
\text { Schwarz criterion } \\
\text { Hannan-Quinn criter. } \\
\text { Durbin-Watson stat }\end{array}$}} & 2678656. \\
\hline Adjusted R-sq & 0.793703 & & & 1189178. \\
\hline S.E. of regression & 540123.6 & & & 29.36855 \\
\hline Sum squared resid & $8.75 E+12$ & & & 29.59074 \\
\hline Log likelihood & -508.9496 & & & 29.44525 \\
\hline F-statistic & 33.70278 & & & 2.099404 \\
\hline Prob(F-statistic) & 0.000000 & & & \\
\hline
\end{tabular}

Source: Processed from the test results with Eviews11

\section{Partial Significance Test (T-tes)}

Unlike the simultaneous test, the partial test (t-test) is used to see the effect of each independent variable partially to the dependent variable. The t-test is done by looking at the probability value ( $p$-value) of each independent variable then the result is compared to the significance level used. This study uses a significance level of $5 \%(\alpha=0.05)$. If an independent variable has a p-value below the level of significance (0.05), the variable is significant so that $\mathrm{HO}$ is rejected and $\mathrm{Ha}$ is accepted. Conversely, if the $\mathrm{p}$-value of a variable exceeds 0.05 , Ha is rejected and $\mathrm{H} 0$ is accepted. The t-test was carried out using EViews11 application. The probability value of this application displays the level of significance for two-tailed hypothesis testing. The results of the $t$ statistical test in this study are presented in the Table of Regression Test Results with the following explanation.

The steps taken to perform the t-test are regressing the main research model using the method that has been previously selected by looking at the Prob value. for each research independent variable. The Regression Test Results table shows the coefficient value of each independent variable, the standard error value, the t-Statistic value, and the significance probability value (Prob.). The influence of the independent variables on the results of the labor market structure can be explained as follows:

1. The effect of the digital economy (ED ) on the labor market structure 
in the transportation sector (TRANS)

The first hypothesis in this study provides a provisional estimate of the effect of the digital economy (ED) on the labor market structure in the transportation sector (TRANS). The null hypothesis and alternative hypothesis made on this variable are as follows:

$\mathrm{H} 0$ : The digital economy (ED) has no effect on the labor market structure in the transportation sector (TRANS)

Ha1: The digital economy (ED) affects the labor market structure in the transportation sector (TRANS)

Prob Value. from the ED variable is 0.0966. This value is above the value of $\alpha=0.05$. Thus, the digital economy variable (ED) has no effect on the labor market structure in the transportation sector (TRANS). Thus, Ha1 is rejected and $\mathrm{HO}$ is accepted.

2. The effect of Investment (INV) on the labor market structure in the transportation sector (TRANS)

The first hypothesis in this study provides a provisional estimate of the effect of investment (INV) on the labor market structure in the transportation sector (TRANS). The null hypothesis and alternative hypothesis made on this variable are as follows:

H0: Investment (INV) has no effect on the labor market structure in the transportation sector (TRANS)

Ha1: Investment (INV) affects the labor market structure in the transportation sector (TRANS)

Value Prob. of the INV variable is 0.0200 . This value is above the value of $\alpha=0.05$. Thus, the investment variable (INV) affects the labor market structure in the transportation sector (TRANS). Furthermore, Ha1 is accepted and $\mathrm{HO}$ is rejected.

3. The influence of COVID-19 Pandemic (COV) on the labor market structure in the transportation sector (TRANS)

The first hypothesis in this study provides a provisional estimate of the influence of COVID-19 pandemic $(\mathrm{COV})$ on the labor market structure in the transportation sector (TRANS). The null hypothesis and the alternative hypothesis made on this variable is as follows:

H0: COVID-19 Pandemic (COV) does not affect the labor market structure in the transportation sector (TRANS)

Ha1: COVID-19 Pandemic (COV) effect on the labor market structure in the transportation sector (TRANS)

Prob Value. from the COVID-19 pandemic $(\mathrm{COV})$ variable is 0.0000 . This value is still below the value of $\alpha=0.05$. Thus, the COVID-19 pandemic $(\mathrm{COV})$ variable has an effect on the labor market structure in the transportation sector (TRANS). Furthermore, Ha1 was accepted and $\mathrm{H} 0$ was rejected.

4. The effect of the Job Creation Law (UUCK) on the labor market structure in the transportation sector (TRANS)

The first hypothesis in this study provides a provisional estimate of the effect of the Employment Creation Law (UUCK) on the labor market structure in the transportation sector (TRANS). The null hypothesis and alternative 
The Labor Market Structure of Transportation Sector in Indonesia: Digital Economy, Investment, Pandemic COVID-19, Job Creation Law

hypothesis made on this variable are as follows:

H0 : The Job Creation Law (UUCK) has no effect on the labor market structure in the transportation sector (TRANS)

Ha1 : The Job Creation Law (UUCK) affects the labor market structure in the transportation sector (TRANS)

Prob Value. from the variable of the Job Creation Act (UUCK) is 0.0338 . This value is still below the value of $\alpha=0.05$. Thus, the variable of the Job Creation Law (UUCK) has an effect on the labor market structure in the transportation sector (TRANS). Furthermore, Ha1 was accepted and $\mathrm{H} 0$ was rejected.

Based on the explanation of these variables, an overview of the coefficient values, namely the Prob value, is compiled. That overview has been adjusted for the research hypothesis that has been made. A summary of the regression results and their interpretations are described in the following table.

Table 3. Summary of Regression Result

\begin{tabular}{|l|c|c|c|l|l|}
\hline Variable & Coefficient & Prob. & A & Interpretation & \multicolumn{1}{|c|}{ Information } \\
\hline ED & -0.002666 & 0,0966 & 0.05 & $\begin{array}{l}\text { Does not } \\
\text { affect the }\end{array}$ & $\begin{array}{l}\text { hypothesis is } \\
\text { rejected }\end{array}$ \\
\hline INV & -862.9158 & 0.0200 & 0.05 & affects & $\begin{array}{l}\text { the accepted } \\
\text { hypothesis }\end{array}$ \\
\hline COV & -3089530 & 0.0000 & 0.05 & $\begin{array}{l}\text { Has effect on } \\
\text { the }\end{array}$ & $\begin{array}{l}\text { anhypothesis } \\
\text { accepted }\end{array}$ \\
\hline UUCK & 1056495 & 0.0338 & $\begin{array}{l}0.05 \\
\text { the }\end{array}$ & effect of the & $\begin{array}{l}\text { hypothesis is } \\
\text { accepted }\end{array}$ \\
\hline
\end{tabular}

Source: Processed from the results of the EViews11

The main regression equation in this study is as follows:

$$
\begin{gathered}
\text { TRANSt }=\alpha 0+\beta 1 \mathrm{EDt}+\beta 2 \mathrm{INVt}+ \\
\beta 3 \mathrm{COVt}+\beta 4 \mathrm{UUCKt}+\varepsilon \mathrm{t}
\end{gathered}
$$

After the researcher performed multiple linear regression analysis using EViews version 11 , the regression equation is obtained with the following coefficients:

TRANSt $=9110665-0.002666 \mathrm{EDt}-$

$$
\text { 862.9158INVt - 3089530COVt + }
$$

$$
1056495 \mathrm{UUCK}+\mathrm{\varepsilon t}
$$

The results of the equation can be explained as follows:

$\alpha t$ is a constant or an intercept of the regression equation for the labor market structure in the transportation sector (TRANS) with a value of 9110665 . This figure shows that if all independent variables' value is constant, the proxy for the structure of the labor market in the transportation sector (TRANS) is worth 9110665.

$\beta 1$ is the coefficient of the independent variable ED. The value of $\beta 1$ of -0.002666 indicates that if there are conditions that increase the digital economy (ED) by one basis point, the value of the labor market structure in the transportation sector (TRANS) will experience a decrease of 0.002666 basis points. These fluctuations assume that other factors affecting the structure of the transport sector labor market (TRANS) are constant (ceteris paribus).

$\beta 2$ is the coefficient of the independent investment variable (INV). The value of $\beta 2$ of -862.9158 indicates that if there is an increase in investment 
The Labor Market Structure of Transportation Sector in Indonesia: Digital Economy, Investment, Pandemic COVID-19, Job Creation Law

Email: sprnwijaya@pknstan.ac.id

(INV) by one basis point, the value of the labor market structure in the transportation sector (TRANS) will decrease by 862.9158 basis points. These fluctuations assume that other factors affecting the labor market structure in the transportation sector (TRANS) are constant (ceteris paribus).

$\beta 3$ is the coefficient of the COVID-19 pandemic independent variable $(\mathrm{COV})$. The value of $\beta 3$ is 3089530 indicates that in the event of a COVID-19 pandemic (COV), the value of the labor market structure in the transportation sector (TRANS) will decrease by 3089530 basis points. It happens based on the assumption that other factors affecting the labor market structure of the transportation sector (TRANS) are constant (ceteris paribus).

$\beta 4$ is the coefficient of the independent variable of the Job Creation Act (UUCK). The value of $\beta 4$ of 1056495 indicates that if the Employment Creation Act (UUCK) is implemented, the value of the labor market structure in the transportation sector (TRANS) will increase by 1056495 basis points. These fluctuations assume that other factors affecting the structure of the transport sector labor market (TRANS) are constant (ceteris paribus).

\section{Coefficient Determination}

The coefficient of determination (R2 indicates whether a regression model estimated is good or not. This coefficient is used to measure the extent of the model's ability in explaining variations of the dependent variable (Ghozali, 2013). R2 value of this research can be seen from the results of the regression in this study which were obtained by doing multiple linear regression test. The larger the value of $\mathrm{R} 2$, the more capable indepentent variables to explain dependent variables. The $\mathrm{R}$ squared value in this study was 0.817973 . This value indicates that the research model can explain the variations of the labor market structure in the transportation sector (TRANS) by $81.79 \%$, while the other $18.21 \%$ is explained by other factors outside the variables studied.

The use of R-squared can cause bias towards the number of independent variables included in the model (Ghozali, 2013). Each variable added to the research model will increase the $\mathrm{R}$-squared value regardless of the significant effect of the added variables on the dependent variable. Many researchers state that a regression model that uses more than one independent variable should use the adjusted R-squared as an indicator of determination because the adjusted R-squared fluctuates when an independent variable is added to the model.

The adjusted R-squared value of this study is 0.793703 , which means that the structure of the labor market in the transportation sector (TRANS) can be explained by the research variable of $79.37 \%$. Meanwhile, the remaining $20.63 \%$ is explained by other influences outside the variables studied. The results of the determination coefficient test can be seen in the Regression Test Results table.

\section{Implications}

Based on the results of the study, it is found that at the $5 \%$ level of confidence, the digital economy has no effect on the labor market in the 
The Labor Market Structure of Transportation Sector in Indonesia: Digital Economy, Investment, Pandemic COVID-19, Job Creation Law

Email: sprnwijaya@pknstan.ac.id

transportation sector in Indonesia. However, if the level of confidence becomes $10 \%$, the digital economy will affect the structure of the labor market in Indonesia. These results are related to previous studies (Morin, 2016; Frey \& Osborne, 2013; Cakranegara, 2020). However, these results refute the findings of previous research which states that the digital economy absorbs labor (Nomura, 2015; Woetzel et al., 2014). Meanwhile, the influence of the investment variable on the labor market structure of the transportation sector is significant. These results are consistent with the research from Dimas \& Woyanti (2009). The COVID-19 pandemic also affects the labor market structure of the transportation sector and is in accordance with previous research (Cakranegara, 2020). And finally the Job Creation Law also affects the structure of the labor market. These results strengthen the results of descriptive analyzes conducted by previous studies (Jumanah, 2020; Hanifah, 2021).

\section{CONCLUSION}

This study is intended to determine the factors that affect the structure of the labor market in the transportation sector. The regression of time series data and the analysis that has been done have resulted in several conclusions regarding the variables studied. Investment, the COVID-19 pandemic, and the Job Creation Law is proven to have an effect on the structure of the labor market in the transportation sector. Meanwhile, the digital economy has proven to have no effect on the labor market structure of the transportation sector. The structure of the labor market in the transportation sector can be explained by the independent variable used in the study of $79.37 \%$ while the remaining $20.63 \%$ is explained by other influences outside the variables studied.

\section{RECOMMENDATION}

The government in controlling the structure of the labor market should pay attention to the investment made by companies. So far, investment policies have focused on capital intensive, which has resulted in a decline in the labor market. The government should also be able to control the COVID-19 pandemic because the pandemic has been proven to greatly affect the decline in the labor market. The government should also issue various implementing provisions of the Job Creation Law, because it has proven to have an effect on improving the labor market. To study the digital economy variable especially the transportation sector, other proxies could be used, for example business circulation or the number of entrepreneurs utilizing information technology.

\section{REFERENCES}

Acemoglu, D. (1999). Changes in unemployment and wage inequality: An alternative theory and some evidence. American Economic Review, 89(5), 12591278.

Aistleitner, C., \& Berkes, I. (2010). On the central limit theorem for $\mathrm{f}$ (nkx). Probability Theory and Related Fields, 146(1), 267-289.

Autor, D. H., Levy, F., \& Murnane, R. J. (2003). The skill content of recent technological change: An empirical exploration. The Quarterly Journal of Economics, 118(4), 1279-1333.

Bardet, J. M., Doukhan, P., Lang, G., \& Ragache, N. (2008). Dependent Lindeberg central limit theorem and some applications. ESAIM: 
The Labor Market Structure of Transportation Sector in Indonesia: Digital Economy, Investment, Pandemic COVID-19, Job Creation Law

Probability and Statistics, 12, 154172.

Bellhouse, D. R. (2001). The central limit theorem under simple random sampling. The American Statistician, 55(4), 352-357.

Cakranegara, P. A. (2020). Pandemi covid 19 dan pengaruhnya terhadap pasar tenaga kerja di Indonesia. Proceeding Working Papers Series in Management, 12(2), 36-46.

Colburn, A. (2009). Central limit theorem. The Science Teacher, 76(9), 10.

Dassau, K. J., \& Hasbun, J. E. (2004). Demonstrating the central limit theorem using MATLAB. Georgia Journal of Science, 62(3), 133.

Dimas, D., \& Woyanti, N. (2009). Penyerapan tenaga kerja di DKI Jakarta. Jurnal Bisnis dan Ekonomi, 16(01), 24257.

Draper, N., \& Smith, H. (1992). Analisis regresi terapan (B. Sumantri (penerj.); 2 ed.). Gramedia Pustaka Utama.

Franke, B. (2005). A functional central limit theorem for diffusions on periodic submanifolds of $\mathrm{R} N$. Probability Theory and Related Fields, 133(2), 236-244.

Frey, C. B., \& Osborne, M. A. (2017). The future of employment: How susceptible are jobs to computerisation? Technological Forecasting and Social Change, 114, 254-280.

Ghozali, I., \& Ratmono, D. (2013). Analisis multivariat dan ekonometrika: Teori, konsep, dan aplikasi dengan EVIEWS 8. Badan Penerbit Universitas Diponegoro.

Gitman, L. J., \& Joehnk, D. M. (2010). Fundamentals of investing (A. Wesley (ed.); 11 ed.). Pearson.
Gray, R. (2013). Taking technology to task: The skill content of technological change in early twentieth century United States. Explorations in Economic History, 50(3), 351-367.

Gujarati, N. D. (2009). Basic econometrics. McGraw-Hill Companies, Inc.

Hanifah, I. (2021). Peluang tenaga kerja asing untuk bekerja di Indonesia berdasarkan rancangan UndangUndang Cipta Kerja. DE LEGA LATA: Jurnal Ilmu Hukum, 6(1), 168-173.

Hartman, A., Kador, J., \& Sifonis, J. G. (2001). Net ready: Strategies for success in the e-conomy. McGraw-Hill, Inc.

Jaimovich, N., \& Siu, H. E. (2012). The trend is the cycle: Job polarization and jobless recoveries (No. 18334; NBER Working Paper).

Jogiyanto. (2014). Teori portofolio dan analisis investasi (10 ed.). BPFE.

Johansen, S., \& Nielsen, M. Ø. (2012). A necessary moment condition for the fractional functional central limit theorem. Econometric Theory, 671-679.

Jumanah, J. (2020). Analisis cost and benefit kebijakan Undang-Undang Cipta Kerja. Jurnal NIAGARA, 12(2), 126-131.

Kutner, M. H., Nachtsheim, C. J., \& J. Neter, J. (2004). Applied linear regression models (4 ed.). McGraw-Hill Companies, Inc.

Miao, Y., Xu, S., \& Peng, A. (2012). Almost sure central limit theorem of sample quantiles. Advances in Decision Sciences.

Miller, R. L., \& Meiners, R. E. (1997). Teori ekonomi mikro intermediate (3 ed.). PT. Raja Grafindo Persada. 
The Labor Market Structure of Transportation Sector in Indonesia: Digital Economy, Investment, Pandemic COVID-19, Job Creation Law

Morin, M. (2015). The labor market consequences of technology adoption: Concrete evidence from the Great Depression. University of Cambridge.

Notohara, M. (2010). An application of the central limit theorem to coalescence times in the structured coalescent model with strong migration. Journal of Mathematical Biology, 61(5), 695-714.

Packard, T. G., \& Montenegro, C. E. (2017). Labor policy and digital technology use: Indicative evidence from cross-country correlations. The World Bank.

Park, B. U., Kim, T. Y., Park, J. S., \& Hwang, S. Y. (2009). Practically applicable central limit theorem for spatial statistics. Mathematical Geosciences, 41(5), 555-569.

Shashkin, A. P. (2006). On Newman's central limit theorem. Theory of Probability \& Its Applications, 50(2), 330-337.

Sholeh, M. (2007). Permintaan dan penawaran tenaga kerja serta upah: Teori serta beberapa potretnya di Indonesia. Jurnal Ekonomi dan Pendidikan, 4(1).

Sudarsono. (1993). Pengantar ekonomi mikro. LP3ES.

Sugiyono. (2016). Metode penelitian bisnis (pendekatan kuantitatif, kualitatif, dan R\&D). Alfabeta.

Sulistiawati, R. (2012). Pengaruh investasi terhadap pertumbuhan ekonomi dan penyerapan tenaga kerja serta kesejahteraan masyarakat di provinsi di Indonesia. Jurnal Ekonomi Bisnis dan Kewirausahaan, 3(1), 29-50.

Sunariyah. (2013). Pengantar pengetahuan pasar modal (6 ed.). UPP STIM YKPN.
Święcki, T. (2017). Determinants of structural change. Review of Economic Dynamics, 24, 95-131.

Tapscott, D. (1996). The digital economy era: Promise and peril in the age of networked intelligence. McGrawHill.

Wasilaputri, F. R. (2016). Pengaruh upah minimum provinsi, PDRB dan investasi terhadap penyerapan tenaga kerja di Pulau Jawa tahun 2010-2014. Jurnal Pendidikan dan Ekonomi, 5(3), 293-250.

Wijaya, S., \& Utamawati, H. (2018). Pajak penghasilan dari ekonomi digital atas cross-boarder transaction. Jurnal Online Insan Akuntan, 3(2), 135-148.

Woetzel, J., Orr, G., Lau, A., Chen, Y., Chang, E., Seong, J., ... \& Qiu, A. (2014). China's digital transformation: The Internet's impact on productivity and growth. McKinsey Global Institute, July, McKinsey\&Company

Woolf, A. G. (1984). Electricity, productivity, and labor saving: American manufacturing, 19001929. Explorations in Economic History, 21(2), 176.

Wulandari, D., \& Harun, M. H. (2020). Pengaruh tingkat suku bunga (BI rate), tingkat inflasi, dan nilai tukar rupiah terhadap hasil investasi perusahaan asuransi syariah di Indonesia tahun 20162018.

Xia, H. Q. (2009). Multidimensional local central limit theorem of some nonuniformly hyperbolic systems. Acta Mathematica Sinica, English Series, 25(4), 565-580. 